\title{
CIPPO Evaluation at School Providing Inclusive Education at Elementary School
}

\author{
Imam Yuwono \\ Universitas Lambung Mangkurat, Indonesia \\ E-mail: imam.plb@unlam.ac.id
}

\begin{abstract}
This evaluation study aims to determine the effectiveness of the implementation of inclusive Elementary School Gadang 2 in Banjarmasin. This evaluation study used a CIPP model and data collection techniques used questionnaires, interviews, observation and study documentation. Analysis of data used qualitative descriptive technique developed by Glickman's with quadrant type. The results of this evaluation study gave a conclusion that implementation of inclusive education program in Gadang 2 Banjarmasin less effective. Some things are not in accordance with the evaluation criteria, namely: the stated goals were not in accordance with the realities today, the recruitment of students with special needs have not done well, the school was not equipped with adequate infrastructure and financing remains low besides social attitudes as a component of outcome was not in accordance with the evaluation criteria.
\end{abstract}

Keywords: evaluation program, inclusive education, CIPP evaluation model

The meaningful value of inclusive education is the creation of a friendly learning for all learners, either ordinary children or children with special needs. The school does not discriminate the learners. All students are entitled to the same education services. Observation result on inclusive education provided at Elementary School of Gadang 2 Banjarmasin have not yet implemented a friendly learning for all children, the perception of school is how the children with special needs are able to learn at regular school and yet many of the public schools still refuse the presence of the children with special needs.

Skjorten states that inclusive education program planning includes the objective and foundation of which the policy of the law should accommodate the needs of all children. The opinion suggests that Government policy that is reflected in the school's policy based on the purpose and foundation of the inclusive education should be organized in such a way, so that the needs of children are accommodated by the constitution without discrimination. The Constitution or its instructions as the foundation of implementing inclusive education is crucial to ensure the fulfillment of needs of all children and adults. The real condition at Elementary School of Gadang 2 is still has not gotten serious attention by the government as it is listed on the constitution. For instance, there has been no obvious coaching either from the Central Government, the province or the city.

The Structure of school providing inclusive education that includes student, teacher, curriculum, infrastructure, financing is arranged in order to support the successful implementation of the program. Johnsen $\&$ Skjorten (2003) state the opinion related to the stance of the school facing a wide range of students with diverse characteristics at an inclusive school is that diversity needs in inclusive classrooms are also giving effect toward an adjustment of the means of learning, media, learning classroom environment setup and social interaction between children in the class. Based on the results of observation at the elementary school that provides inclusive education in Banjarmasin also complains about the way of the curriculum modification, teachers ' competence is still low, the infrastructure is not yet adequate, specific learning media is still lacking, so do the number of classrooms for teaching and learning. Educational background and understanding of classroom teacher about the children with special needs and inclusive education is still low.

The result of the research carried out by Sofyan (2012) that the implementation of inclusive education in at elementary school of Gadang 2 is not optimal yet, since the acceptance of regular school toward the presence of the children with special needs is still low. The availability of infrastructure has not been adequate. Research conducted Yuwono (2013) is that teacher skill at elementary school of Gadang 2 in conducting student assessment is still low. The identification and assessment way toward the children with special needs is still low. The above results indicate that elementary school in Banjarmasin as inclusive education providers has not supported with adequate human resources yet, especially in terms of learning outcomes assessment.

The interview result of Inclusive education Elementary School of Gadang 2 Banjarmasin is that many people complain of a lack of special supervisor. The education funding has not been adequate and supporting infrastructure of inclusive education providers are still limited while the needs of the 
community against the inclusive school are increasingly urgent, due to the the increase of the children with special needs.

\section{METHOD}

The methods used in this study is the evaluation research referring to the evaluation model developed by D.L. Stufflebeam (2001) known as model evaluation CIPP (context, input, process, and product).

The data obtained were analyzed qualitatively using CIPP model with triangulation toward relevant data to the implementation of inclusive education programs referring to the criteria that have been set then interpretation and conversion of the achievement indicators are conducted to know whether they are appropriate or not in accordance with the evaluation criteria. If it is in accordance with the evaluation criteria, it is given a positive sign $(+)$. However, if it is not, it is given negative mark (-). The next step is to conduct a mapping of quadrants in accordance with evaluation criteria that has been set in accordance with the Glicman quadrant prototype image.

\section{FINDINGS AND DISCUSSION}

\section{Findings}

The research result related to the evaluation with context of the holding of inclusive education at elementary school of Gadang 2 Banjarmasin, is found that school in the indicator of objective is less effective (not appropriate with evaluation criteria) while the indicator of formal foundation is effective, indicator of couching is also less effective, and the indicator of the need and feasibility of school is less effective. The operational foundation of inclusive education at elementary school of Gadang 2 Banjarmasin is permendiknas (ministry constitution of national education) number 70 in 2009, then it is followed up by Education directorate of (PKLK) pendidikan khusus dan layanan khusus (the special education and special services) through the manual book of holding program of inclusive education. The supervising mechanism in the central level is couched by the Directorate of PKLK of Dikdas (elementary education). At province level, it is coached by the head of the provincial education by head of division of elementary school supervising. The level of city is handled by elementary education of city especially by elementary school section, and the school level was built directly by the school principal who was assisted by vice Coordinator curriculum and inclusive. Structurally institution mechanism has been clear from a coaching education inclusive program from the central level to units of the school. The evaluation results on the indicator of needs analysis and school feasibility found that international conference in Spain which was held in 1994 generates a statement of Salamanca, for instance on a second grain; (1) every child has the fundamental right to earn education, and must be given the opportunity to achieve and a keep reasonable level of knowledge, (2) those who have special needs should have access to regular schools that accommodate them in order of child-centered education and can meet their needs , (3) inclusive Education should provide education that will prevent the kids develop poor self-esteem and the consequences that may happen. Inclusive education need analysis conducted through SWOT analysis against four elementary schools that provide inclusive education in Banjarmasin retrieves data as follows: The strength of the schools that provide inclusive education is characterized by having a school service team. That is a strong inclusion program. The School is interested by community as organizer of inclusive education among the people. The School becomes the proudness of and expectations of parents of the children with special needs and community. The Number of parents who have children with special needs who have strong commitments to send them in Banjarmasin are very powerful forces that encourage inclusive school that is awaited its presence by many communities.

The results of the evaluation on the input component found that the process of recruitment of students at elementary school of gadang 2 is still less effective due to several factors including: (1) Unaware of parents in the importance of conducting identification, so the verification to expert people is not conducted. (2) Teachers have lack of knowledge about children with special needs. Socio-economic circumstances of the four schools are different and graded from the Middle society. This Socio-economic condition will greatly affect the attention of children's education.

The indicator of administration conditions of teacher in schools that provide inclusive education at elementary school of Gadang 2 is still not in accordance with the evaluation criteria. This has connotation that someone who has a diploma in teaching at elementary education is judged to have capability in teaching. The Evaluation of inclusive education in curriculum at elementary school of Gadang 2 is less effective, pointing out that the teachers in developing a curriculum has not been oriented on the conditions of the student needs.

The Availability of infrastructure shows value of less effective (not appropriate with evaluation criteria). The financing aspect shows that it is still less effective. The school does not yet have a standard financing for each student, though it already has the RKAS (School Financing Activity Plan) which is containing income and outcome funds overall. School funding is still not able to sustain the needs of the school. The evaluation result of the process is found that the teacher's competence 
at elementary school of Gadang 2 is at good category that means that teachers have competences such as curriculum defferentiation, curriculum modification, individual learning, cooperative learning, motivating to learn and flexible assessment.

The results of the evaluation of the product found that the school has experienced an increase in the national exam score when it becomes inclusive education providers. It means that inclusion at a school does not affect the national exam score. The social aspect of the school that has been long time holding inclusive education shows effective criteria while at the new school which organizes the inclusive education indicates less effective the criteria. The evaluation results of outcomes found that elementary school of Gadang 2 has good outcomes, in accordance with the evaluation criteria.

The effectiveness of the implementation of inclusive education programs at elementary school of Gadang 2 is looked at the mapping data acquired on the results of analysis of the components of the context, input, process, product and outcomes as follows:

Elementary school of Gadang 2 at context component value $(+,-,+,-)$ input component value $(-,+$, $+,+,-,-)$ the process component value $(+,+,+)$ product component value $(+,-)$ learning outcomes component value $(+)$.

The evaluation result of the implementation of inclusive education at four elementary schools in Banjarmasin refers to the quadrant prototype of Glikman. Based on the results of the mapping shows the CIPP criteria is (+-+---). The "+" sign means in accordance with the evaluation criteria or it is effective, and the sign "-" means not in accordance with the evaluation criteria or it is not effective. If it is converted into quadrants prototype by Glikman, then the effectiveness of the implementation of inclusive education program elementary school located at Gadang 2 is at quadrant IV (four) or less effective or less accordance with the evaluation criteria. It means that the context component is effective (in accordance with the evaluation criteria), input component is not effective (not in accordance with the evaluation criteria), the process components is effective (in accordance with the evaluation criteria), the component of the product is not effective (not in accordance with the evaluation criteria), and the component of outcome is effective (in accordance with the evaluation criteria). Thus, that the implementation of inclusive education programs in elementary school in Banjarmasin includes less effective or less in accordance with the evaluation criteria.

\section{Discussion}

The evaluation results of context component as in purpose indicator is still dominant in gearing to protect children with special needs both super and under to support their education in public schools. They get treatment without any discrimination in terms of education. The purpose of inclusive education that listed on Permendiknas No. 70 of 2009 seems no longer appropriate in the current era. The presence of children with special needs in regular schools is also going to affect the attitude and the mental of other learners generally such as appreciating the diversity, helping each other and cooperating each other. The school system such as curriculum and assessment adjust the conditions of each learner. Here is needed a child-friendly learning system that respects individual differences. Every single member of school grows a friendly attitude and mutual respect. This is according to the opinion of Skørten that the purpose of inclusive education is to reduce fear and build, grow the loyalty of friendship and build a sense of understanding and appreciating.

Formal base document is owned by the school that has evaluated. Through the various interview of school stakeholders, Gadang 2 Elementary School understands the formal base very well. Formal base is understood by school community and provide benefits in achieving the goal of inclusive education. This is similar to the opinion that the base that overarch inclusive education can provide benefits to all children without any discrimination, and help to create an inclusive society.

Based on the findings in the field there are indications of a loose fostering, especially on aspects of monitoring, supervision, and evaluation of school organizer of inclusive education. It programmed periodically at least once a year. PKLK Directorate of Primary Education, Provincial Education Department and sub Department of district only received a written report of the practice of program implementation reported by school. Fostering of the school organizers of inclusive education remains low. There is no excellent fostering yet from the center to the province, it remains unclear. In Education Department of South Borneo, the fostering of inclusive school is submitted to each sub Department such as Subdin Dikdas (Sub Department of Primary Education) fosters inclusive school at elementary level, Subdin Bina menengah (Sub Department of intermediate Education) fosters inclusive school at intermediate level. In Gadang 2 Elementary school, inclusive education program is fostered by supervisor of disability school. There is no clarity regarding the fostering structure of inclusive school. Fostering of inclusive elementary school in Banjarmasin is low, it takes a total change.

The Evaluation toward economic background indicator of parent at elementary school of Gadang 2 shows less effective (less suitable with the evaluation criteria). Socio-economic condition of parent is at low 
Middle. This condition triggers the lack of sufficient guidance and direction from their parents, because the parents are more focused on how to meet the daily needs. It is Similar with opinion by Bahar in Jericho that generally, the child who comes from a intermediate and high class family in terms of socio-economic condition has more got a briefing and guidance from their parents. The school attempts to address this issue include teachers through a variety of training, so that the learning process of the children with special needs in accordance with specific conditions and needs.

Competence of teachers who are less effective will affect the planning and implementation of the curriculum. It is similar with the opinion by Michaell that curriculum of inclusive education must be arranged flexibly according to the needs and the conditions of the school. It can be driven by the ability of teachers in implementing the learning. The Teacher Interest in teaching at elementary school of Gadang 2 as Inclusive education providers fall into the good category (in accordance with the evaluation criteria), it indicates that the teachers feel happy, able to accept the children with special needs, sincere and proud in performing learning with children with special needs. The evaluation results of the learning process at elementary school of Gadang 2 show good and very good category and this needs to be maintained. The process of learning at the school involves students in learning. Student involvement could be interpreted as students play an active role as a participant in the process of teaching and learning. It is similar with the opinion by Sudarwan Darwin that the teacher is able to give students the opportunity to be active, either finding, processing or managing their learning acquisition.

The evaluation result of the component of cognitive products of elementary school of Gadang 2 is in category that is in accordance with the evaluation criteria that are set. National examination score continues to improve for years during it is being inclusive education providers. The presence of students with special needs at regular school does not affect the value of the average score of national exam. Children with special needs with cognitive barriers only take the school test they do not have to follow the national exam. Social attitude appropriates with evaluation criteria. The Elementary school of Gadang 2 which has long hosted the inclusive education has better social attitude, the presence of children with special needs trains other students to have mutual help and togive sympaty. The longer they are interacting, the better they will grow positive social attitude. The opinion of Samsudin Abib that social attitude of someone is looked in the pattern of responses between people manifested with mutual interpersonal relationship after doing long interaction. This opinion indicates that the longer they are doing interaction, the better the students will grow the positive social attitude.

The evaluation result of outcome component, continuity of study by children with special education is in accordance with specific evaluation criteria thatare set. Most graduates of the elementary school of Gadang 2 can continue the study. It means that the outcome in terms of conducting of inclusive education at Gadang 2 needs to keep pushed, to get the attention of the various concerned parties.

\section{CONCLUSION AND SUGGESTION}

First, the context component: inclusive education objective laid out at permendiknas (ministry constitution of national education) number 70 in 2009 needs to be reviewed because it is not suitable with inclusive school needs. The flow of funding either at a central, province or city, does not run well because there is not a clear flow. The requirement and feasibility level of schools are effective in accordance with the evaluation criteria.

Second, an input component includes: Recruitment of students with special needs implements well. Socio-economic background of the parents is in middle-scale or medium, then with the such condition, schools should be more involved various activities so that medium socioeconomic level can support the program inclusive better. The administrative requirement for elementary school teachers of Gadang 2 has not been appropriate either qualification, teaching experience or in following various training. The Aspect of the curriculum has meet the relevance including defferentiation, orienting on the learners, covering social attitude, flexible with conditions of the children. The Facility and infrastructure of the elementary school of Gadang 2 have complete infrastructure and facilities in accordance with the specified criteria. The Financing aspect still relies solely on low cost of BOS (School Operation Fund) which is still not sufficient. All schools feel mind to bear with special supervisor salary.

Third, the component of the process includes: the competence of teachers, teaching and learning interest in teaching in the inclusive classroom. Aspects of teacher competencies that include curriculum modification, modifying curriculum, doing individual learning, cooperative learning, motivating students, conducting a flexible assessment are effective at elementary school of Gadang 2. The Aspect of teaching interest has effective interest shown with happiness, sincerity, pride and acceptance attitude towards receiving students with special needs. The Aspects of learning in inclusive class that include conditioning of learning, learning strategies, student involvement, mastery learning materials are very well.

Fourth, the cognitive product obtained by elementary school of Gadang 2 Banjarmasin in term of 
National examination is increased. It means that during the implementation of inclusive education does not affect the national exam score at the school. The aspect of social attitude has an excellent social attitude.

Fifth, the component of outcome that is obtained by four elementary school of Gadang 2 Banjarmasin has high outcomes. That is $99 \%$ of the children with special needs can continue to a higher level of school.

\section{REFERENCE}

Glickman, C. D., Stephen. P. G. (204). Supervision and Instructional leadership. Brief Edition. New York: Allyn \& Bacon, Inc.

Johnsen, B. H., \& Skjorten, M. D. (2003). Menuju Inklusi, Pendidikan Kebutuhan Khusus Sebuah Pengantar. Bandung: Program Pasca Sarjana UPI Bandung.

Sofyan. (2012). Manajemen Pendidikan Insklusif di Kalimantan Selatan. Banjirmasin: Unlam Press.

Stufflebeam, D. L. (2001). Evaluasi Model Viewpoints on Educational and Human Services Evaluation. Boston: Kluwer Academic Publisher. 101.

Yuwono, I. (2013). Sistem penilaian dalam pendidikan inklusif di SD Banua hanyar 8 banjarmasin. Banjarmasin: Unlam Pers 